\title{
BIZTONSÁGTECHNIKAI MEGOLDÁSOK AZ ÓBUDAI EGYETEM NÉPSZÍNHÁZ UTCAI KAMPUSZÁN
}

\section{SOLUTIONS BASED ON SAFETY TECHNOLOGY AT ÓBUDA UNIVERSITY CAMPUS, LOCATED IN NÉPSZÍNHÁZ STREET}

\author{
BÁLINT Krisztián \\ (ORCID: 0000-0002-2407-9230) \\ balint.krisztian@phd.uni-obuda.hu
}

\begin{abstract}
Absztrakt
Napjainkban az egyetemeknek szükségszerü olyan modern biztonságtechnikai megoldásokat alkalmazniuk, amely által garantálni tudják az ott tartózkodó hallgatók biztonságát. Tudvalevő, hogy az oktatási intézmények müködéséből kifolyólag igen gyakran nagy számban tartózkodnak az épület falain belül hallgatók és ott dolgozó tanárok. Az ő biztonságuk mindennél fontosabb. Elég csak kitekinteni külföldre, ahol sajnálatos módon, az egyetemeken többször is elöfordult komoly incidens, úgy, mint lövöldözés, gyilkosság.

Ebből kifolyólag került sor az Óbudai Egyetem biztonságtechnikai megoldásainak a megvizsgálásra, hiszen jelen esetben egy olyan neves oktatási intézményröl van szó, amely az évek során számos hallgatónak biztositott tanulási és továbbképzési lehetőséget.

A kutatás részleteiben feltárta azt, hogy az Óbudai Egyetemen igen komoly biztonságtechnikai megoldások kerültek kiépitésre, igy feltételezhetően az ott tartózkodók biztonságban érezhetik magukat.
\end{abstract}

Kulcsszavak: biztonságtechnika, mechanikai védelem, elektronikai védelem

\begin{abstract}
Currently, the universities inevitably need to implement modern solutions based on safety technology, through which they can guarantee the safety of the students on the site. It is widely known that throughout the functioning of the educational institutions, students and the employed educators turn up very often in large numbers within the premises. Their safety is of utmost importance. It is alarming enough to survey the happenings abroad, where there were multiple, serious and regretful incidents at the universities, such as shootings, murders.

Thus, the solutions based on safety technology of Óbuda University came under examination, as it is presently a renowned educational institution, which has been providing possibilities for study and retraining for many years.

The research has uncovered in detail, that Óbuda University has very elaborate solutions based on safety technology implemented, thus, the persons on site may presumably feel safe.
\end{abstract}

Keywords: security technology, mechanical protection, electronic protection 


\section{BEVEZETÉS}

A biztonságtechnika napjaink elengedhetetlen területe [1], amellyel szükségszerü foglalkozni. Ezért vizsgáltam meg az Óbudai Egyetem Népszínház utcai kampuszán alkalmazott biztonságtechnikai megoldásokat, azok müködési mechanizmusait az egyetem mindennapi életében. Ez egy igen bonyolult és komplex feladat volt, hiszen ebben az épületben kapott helyett a Biztonságtudományi Doktori Iskola, amely alapján feltételezhetö, hogy komoly a biztonság és elővigyázatosság az oktatási intézmény falain belül, hiszen már csak a doktori iskola nevéből adódóan laikusként is feltételezhető, hogy a „név kötelez”. Továbbá az épület falain belül kapott helyett a Trefort Ágoston Mérnökpedagógiai Központ, amelyröl tudvalevő, hogy informatikus mérnöktanárok képzése történik magas színvonalon, így hát magát adja, hogy az ott dolgozó tanárok és oktatók jártassak a biztonságtechnikai megoldások területén. Továbbá a Bánki Donát Gépész és Biztonságtechnikai mérnöki kar is az épületben foglal helyet, melyről az előző mondatban írtak szintén elmondhatóak. Ezen referenciákat figyelembe véve sokkal nagyobb elvárások fogalmazódnak meg a kutatóban, hiszen éppen ez az az egyetem, amely feltételezhetően példaértékü biztonságtechnikai megoldásokat alkalmaz a mindennapok során a hallgatóik és az ott dolgozóik biztonsága érdekében.

Sajnálatos módon azonban napjainkban az oktatási intézmények egyre nagyobb veszélynek és fenyegetettségnek vannak kitéve. Számos olyan külföldi esetről számolt már be a sajtó, amikor is hallgatók, illetve az ott dolgozók élete veszélybe került. Ezeket leginkább extrém eseteknek lehet tekinteni, amikor is konkrét életellenes büncselekményekre került sor. A cikknek nem célja a pánik, illetve bizonytalanság keltése az oktatási intézményekben, azonban elsődleges cél az alkalmazott biztonságtechnikai megoldások feltérképezése, megvizsgálása, illetve javaslat tétel a biztonság fokozása érdekében, jelen esetben az Óbudai Egyetemen. Abból kifolyólag, hogy Magyarországon továbbra sem forduljon elő olyan eset, amikor is valakinek az élete az egyetemen veszélybe kerülne, szükségszerü az egyetemek biztonságtechnikai megoldásait behatóbban megvizsgálni. Fontos megjegyezni, hogy sikeres oktatás és nevelés kizárólag békés és veszélymentes iskolai körülmények között jöhet létre.

Jelen kutatás vizsgálni fogja az Óbudai Egyetemen alkalmazott mechanikai és elektronikai védelmi megoldásokat.

1. A kültéri védelem elemei lehetnek:

a. Kapuk,

b. Kerítések.

2. Az építményvédelem elemei közé sorolhatók:

a. Ajtók,

b. Ablakok.

3. Mechanikai tárgyvédelem elemei a következők lehetnek:

a. Zárható bútorok,

b. Különböző zárszerkezetek.

4. Ezen felül feltárásra kerül különböző elektronikai védelmi lehetőségek:

a. Beléptető-rendszer,

b. Videó felügyeleti rendszer.

5. A kutatás végén pedig a tüzvédelmi megoldások kerülnek feltárásra:

a. Tüz és füstjelző berendezések,

b. Tüzoltási megoldások (porral oltó készülékek). 


\section{MECHANIKIA VÉDELMI MEGOLDÁSOK}

\section{Kültéri védelem elemei}

Az oktatási intézmények az objektum kategóriába sorolhatóak, tehát rájuk is ugyanaz a definíció fogalmazható meg, mint a többi objektum esetében.

„Az objektum egy pontosan körülhatárolható terület, melyen felépítmények találhatóak különböző funkciókkal. A veszélyeztetettség mértékét a működés, az üzemeltetés biztonsági foka, a felhasznált különféle anyagok, technikai eszközök, információk kereslete, értéke, értékesíthetősége, a terület bünügyi fertőzöttsége, müködés rendje a napszak, az alkalmazott védelmi rendszer megbízhatósága, a beavatkozás, az elhárítás objektív-szubjektív gyorsasága, a nemkívánatos cselekmények jellege és azok területi kihatása határozza meg." [2]

Ahhoz, hogy a megfelelő mechanikai védelmet kialakítsunk, számos kockázati tényezőt figyelembe kell venni.

Első lépésként a várható biztonsági kockázatokat kell értékelni a normál müködéshez képest, mint pl., hogy milyen biztonsági kockázati tényezők fordulnak elö, hogyan és milyen időtartamra változhatnak, stb. Már az objektumvédelmi rendszer tervezési időszakában szükséges az állapotfelmérés és a kockázatelemzés elvégzése, majd ezek alapján lehetséges az értékelés és a javaslat kidolgozása. A kockázatelemzés során az adott létesítménnyel, üzemeltetésével és a benne folyó tevékenységekkel kapcsolatban esetleg előforduló lehetséges kockázatok azonosítását és értékelését szükséges elvégezni. A gyakorlati tapasztalat azt erősíti, hogy a tervezési időszakban un. várható biztonsági kockázati szcenáriók kidolgozása, az azokra történő védelmi szervezeti válasz, reagálás megtervezése rendkívül hatékony intézkedéseket tesz szükségessé. [3]

Az oktatási intézmények esetében azonban még figyelembe kell venni azt is a kockázatelemzés során, hogy ezek milyen időközönként müködnek. Tudvalevő, hogy nyári és a téli szünidő alatt kevesen tartózkodnak az objektumban, ez megnöveli az esélyét egy betöréses lopásnak. Tehát ebben az időszakban a mechanikai védelmi megoldások előtérbe kerülnek. A kapukat zárva kell tartani, illetve a kerítések is megfelelő állapotban kell, hogy legyenek. Az első számú ábra az Óbudai Egyetem elektromos kapurendszerét szemlélteti:

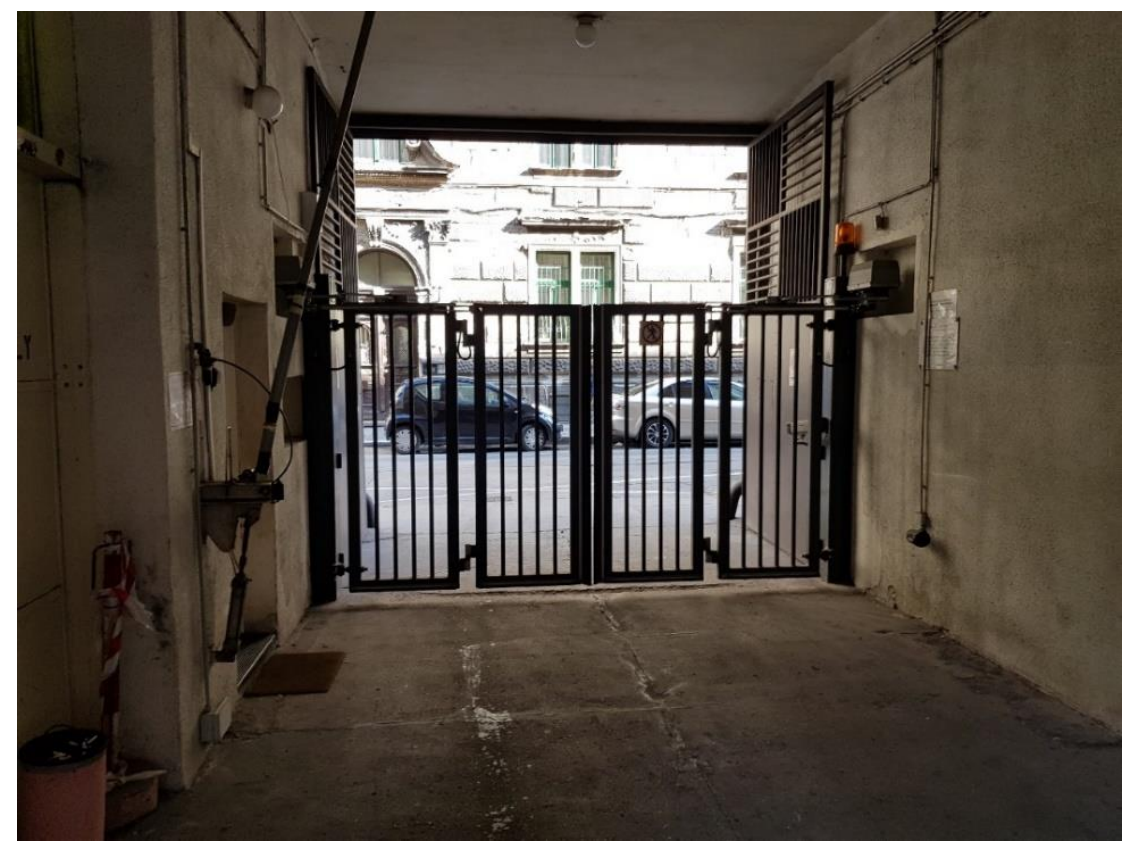

1. ábra $A z$ Óbudai Egyetem elektromos kapurendszere (Forrás: Saját készítésű ábra) 
Az élőerős védelem nagymértékben fokozza az egyetem biztonságát. Az elektromos kapu müködtetése az ö feladatkörében tartozik. Jelen esetben személygépjármüvel illetéktelen személyek nem hajthatnak be, nem parkolhatnak szabálytalanul a bejárat elé. A behajtás engedély köteles, amelyet az oktatási intézmény adhat az ott dolgozók, illetve egyes esetekben a hallgatók számára. A kapu masszív vasból készült, amelynek tartóelemeit betonfal veszi körül. A kapu nyitásakor és zárásakor biztonsági jelzőfény figyelmeztet, amely a kapu tetején van elhelyezve, ezzel jelezve az utcán közlekedő gyalogosok számára, hogy személygépjármü érkezik, óva intve az elővigyázatosságra. Behajtás esetén a biztonsági személyzet leellenőrzi a behajtási engedélyt. Amennyiben minden rendben van, úgy a személygépjármüvel a sorszámozott parkolóba be lehet hajtani. A biztonsági személyzet minden egyes esetben közli, hogy melyik parkolóhelyet lehet elfoglalni. Ez után a személyzet azt illető nevét és a személygépjármủ rendszámtábláját rögzíti a saját rendszerébe. Az érkezés és távozás időpontja feljegyzésre kerül. Pozitív élményként fogalmazható meg, hogy a biztonsági személyzet kedves és segítőkész.

Az Óbudai Egyetem építészeti struktúrájából adódóan mindössze egy kapuval rendelkezik. Kerítésre nincsen szükség, mivel a kerítés feladatát az épület falai látják el. Környezetének hátat fordító belső udvarral tájolt épületröl van szó.

\section{Az építményvédelem elemei}

Mint ahogyan már fentebb említésre került, ebben a kategóriában leginkább az ajtók, ablakok tartoznak, de ide tartoznak még a rácsok, fóliák, födémek, stb.)

Az egyetem egy masszív fából készült főbejárati ajtóval rendelkezik. Ezt a második számú ábra szemlélteti:

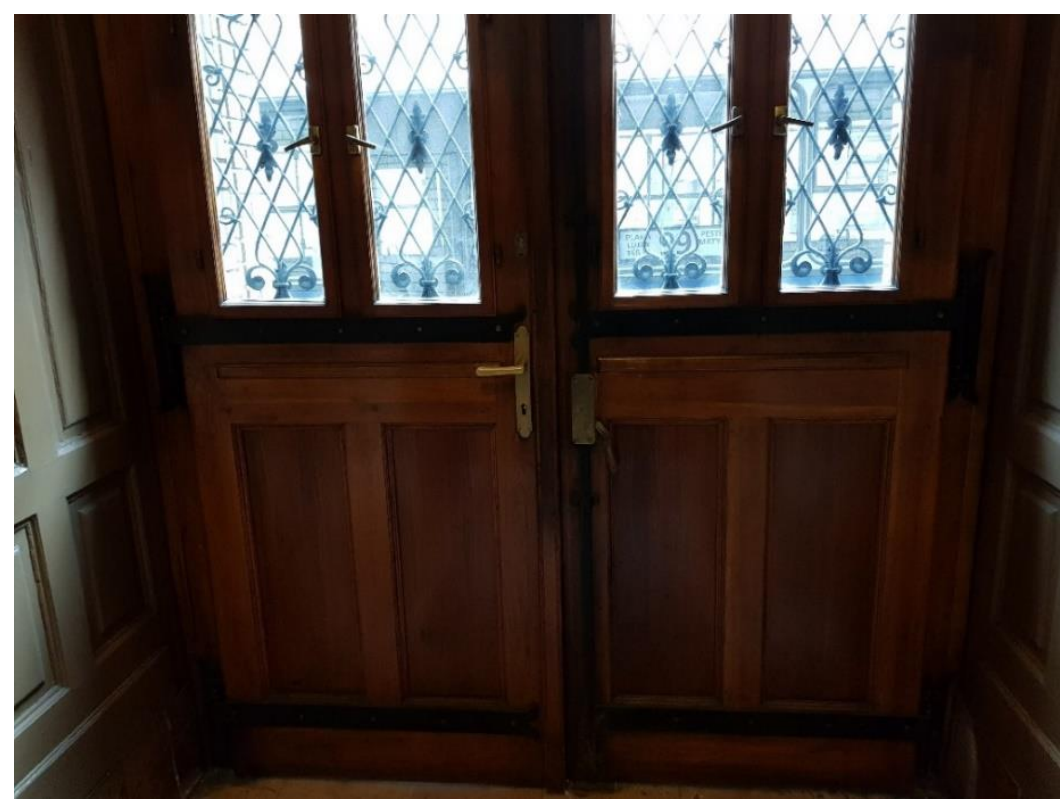

2. ábra Népszínház utcai Óbudai Egyetem bejárati ajtaja (Forrás: Saját készítésű ábra)

Bejárati ajtó ablakaira rácsok vannak elhelyezve, ezzel is növelve a biztonságot. Ezen felül belülről az ajtó vaspántokkal van megerösítve. Ez a harmadik számú ábrán jól látható: 


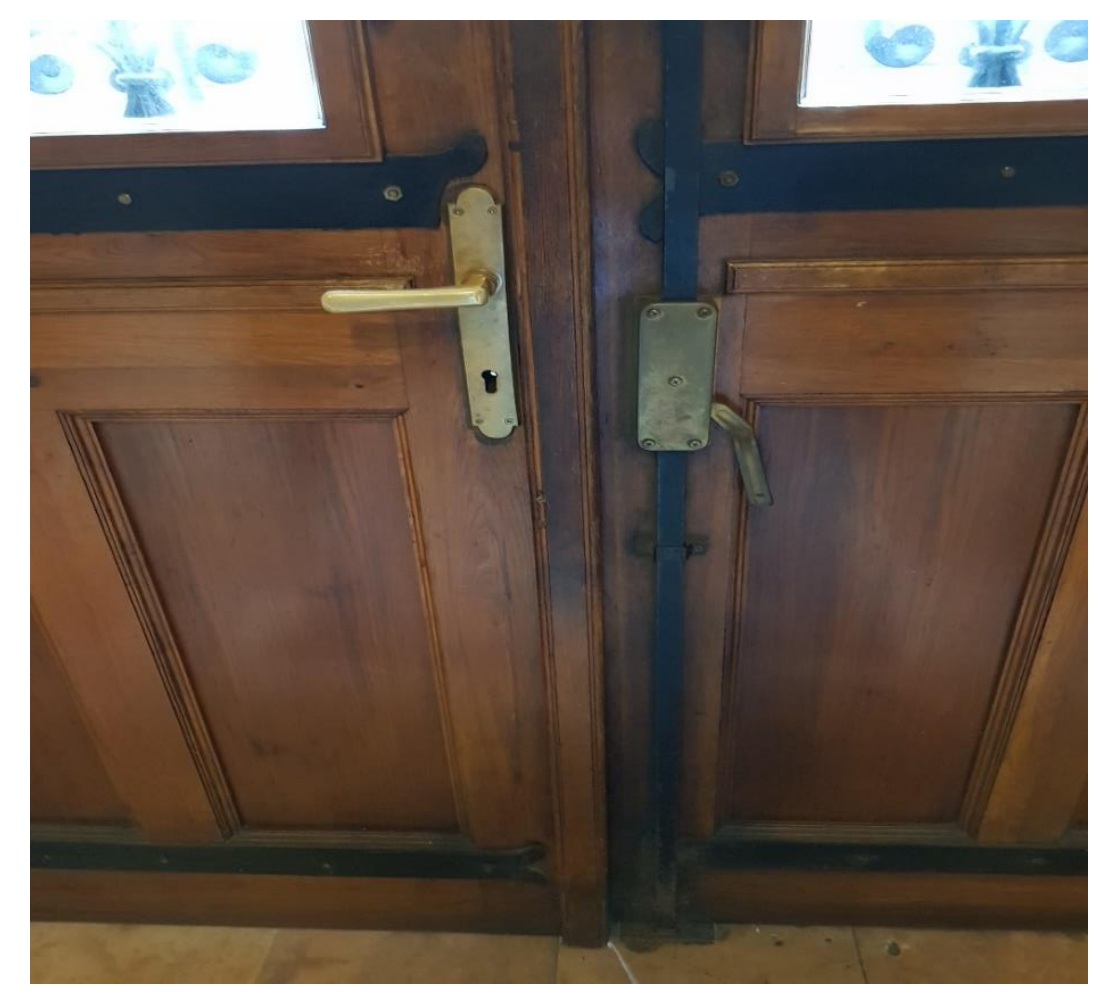

3. ábra Vaspántokkal megerősített bejárati ajtó (Forrás: Saját készítésű ábra)

\section{ELEKTRONIKAI BIZTONSÁGI MEGOLDÁSOK}

\section{Beléptető rendszer}

Napjainkban minden jelentős objektumnál elvárás, hogy vagyonvédelmének részeként egy olyan rendszer kerüljön kiépítésre, melynek fö célja a belépési jogosultság ellenőrzése és az áteresztés megvalósítása mechanikai vagy elektromechanikai berendezések segítségével. Az ellenőrzés megfelelően gyors és megbízható kell, hogy legyen, egyértelműen és minden kétséget kizáróan ki kell szürnie a belépésre jogosultak körét, nem gátolhatja mozgásukat és a nap 24 órájában müködőképes kell, hogy legyen. Az ilyen feladatok elvégzésére jöttek létre a beléptető rendszerek. [4] Beléptető rendszerre szükség van minden olyan épületben, ahol a belépést felügyelni kell. [5]

Az egyetemen a portai szolgálattal szemben chip kártyás beléptető-rendszer müködik. Ez a birtok alapú beléptető-rendszer kategóriába esik, amely azt jelenti, hogy csak azok juthatnak be, akik birtokolják a chip kártyát. Az egyetem beléptető rendszerét a negyedik számú ábra szemlélteti: 


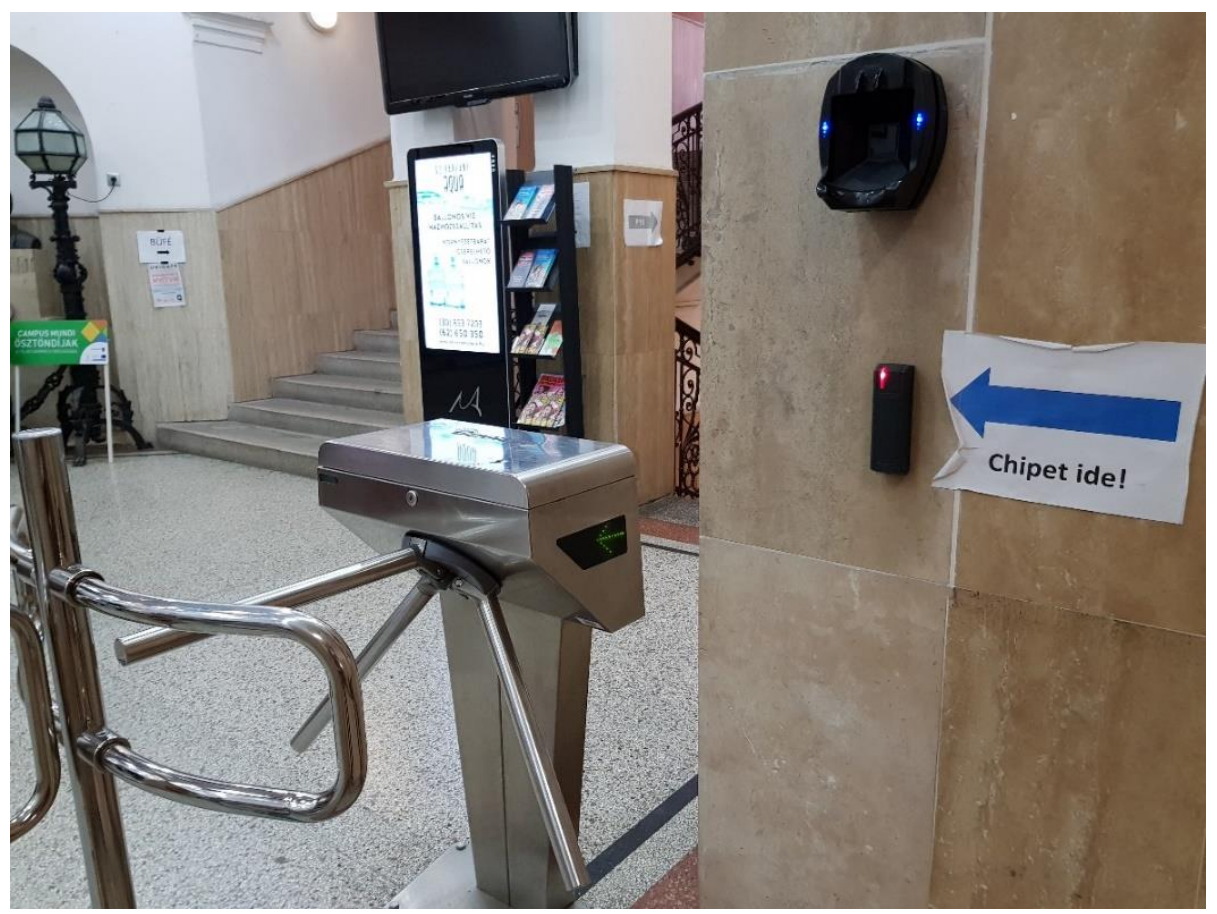

4. ábra Az Óbudai Egyetem lengővillás birtok alapú beléptető rendszere

(Forrás: Saját készítésü ábra)

A birtok alapú azonosításnál az ellenőrzés egy olyan egyedi és mással össze nem téveszthető eszközön alapul, ami egyértelmüen azonosít egy személyt azáltal, hogy annak mindig a jogosult személy birtokában kell lennie. Ilyen eszköz lehet például lyukkártyás, induktív kódolású, vonalkódos, Wiegand rendszerü, mágnes csíkos, érintés nélküli, memóriakártyás és optikai kártyás azonosító. A használata általában ennek a módszernek is egyszerü, a költségeket tekintve pedig léteznek olcsó, de egészen drága megoldások is. A módszer közismert hátránya, hogy amennyiben illetéktelen kezekbe kerül a kulcs, akkor jogosulatlan hozzáférés lehetséges. A tudás alapú azonosítással szemben viszont ebben az esetben - már amennyiben nem másolható kulcsról van szó - az eltulajdonítás ténye érzékelhető, nem úgy, mint a jelszavak esetében. Így ez egyfajta utólagos védelmet nyújt azáltal, hogy az ellopott kulcs utólag letiltható. Éppen ezért itt az egyik legfontosabb követelmény a kulcsokkal szemben, hogy ne legyenek másolhatók. Ezen felül fontos müködési elvárás a vésznyitás lehetőségének biztosítása, ez minden rendszernél alapvető követelmény. A rendszernek lehetővé kell, hogy tegye azt, hogy rendkívüli esemény bekövetkezésekor az áteresztési pontok azonnal müködésbe kerüljenek és kinyitódjanak, annak érdekében, hogy a bent tartózkodó személyek biztonságban ki tudjanak menekülni. [6] Az ötödik ábra jól szemlélteti, hogy az egyetemre való bejutás csak ellenörzött körülmények között lehetséges. A beléptető rendszer esetében a vésznyitás lehetősége is biztosított. 


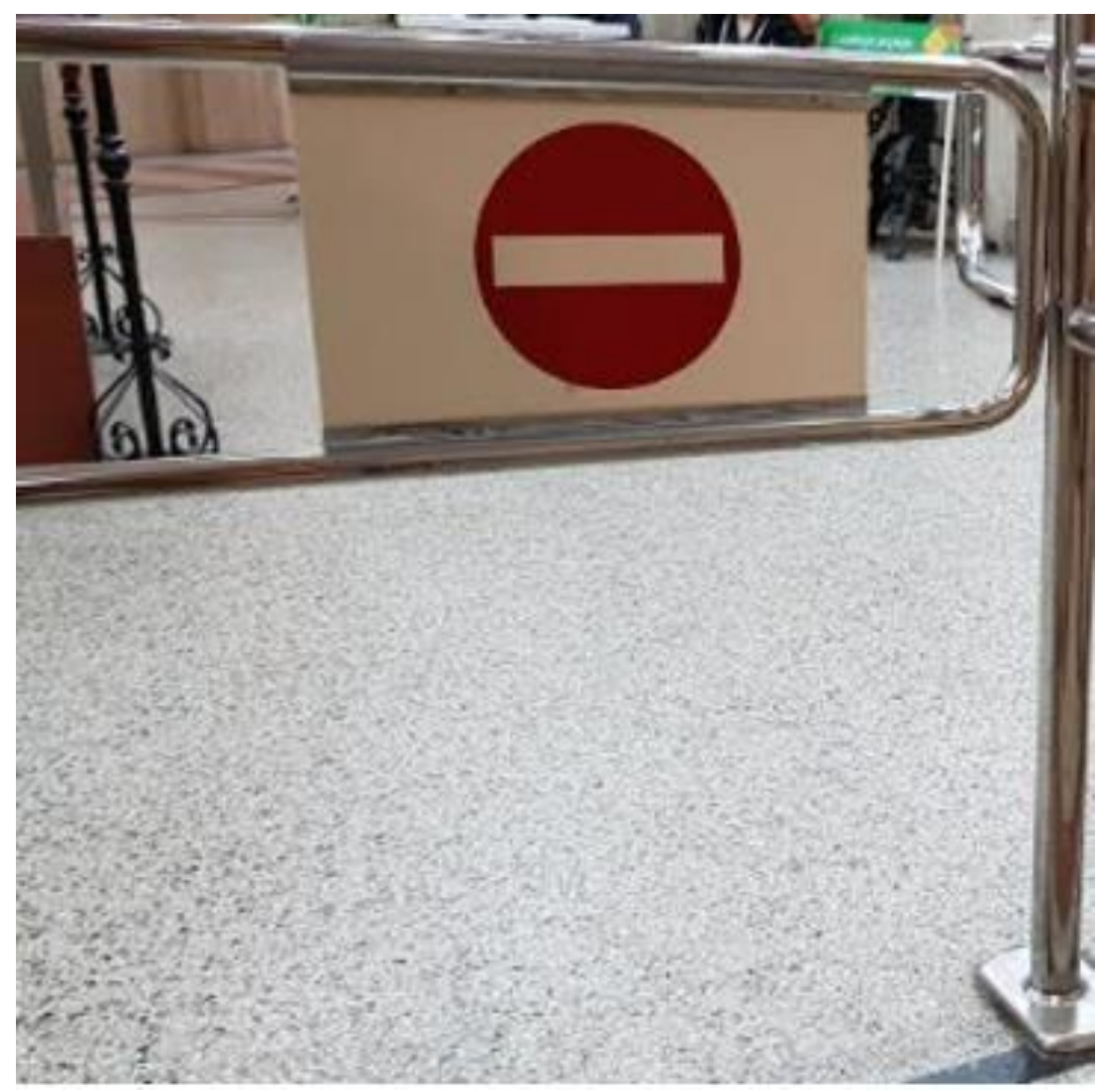

5. ábra Az Óbudai Egyetem lengővillás beléptető rendszere (Forrás: Saját készítésű ábra)

\section{Video felügyeleti rendszer}

A biztonsági kamerarendszerek fontos szerepet töltenek be. [7] Napjainkban megfelelő szintü iskolabiztonságot video felügyeleti rendszer nélkül szinte lehetetlen kialakítani. A biztonsági kamerarendszer nem csak az illetéktelenektől véd, hanem a lopások terén is visszatartó ereje van, hiszen evidens, hogy a kamerarendszer rögzíti az eseményeket, amelyek bizonyítékul szolgálhatnak egyes esetekben. A hatodik ábrán az egyetem megfigyelő helysége látható müködés közben: 


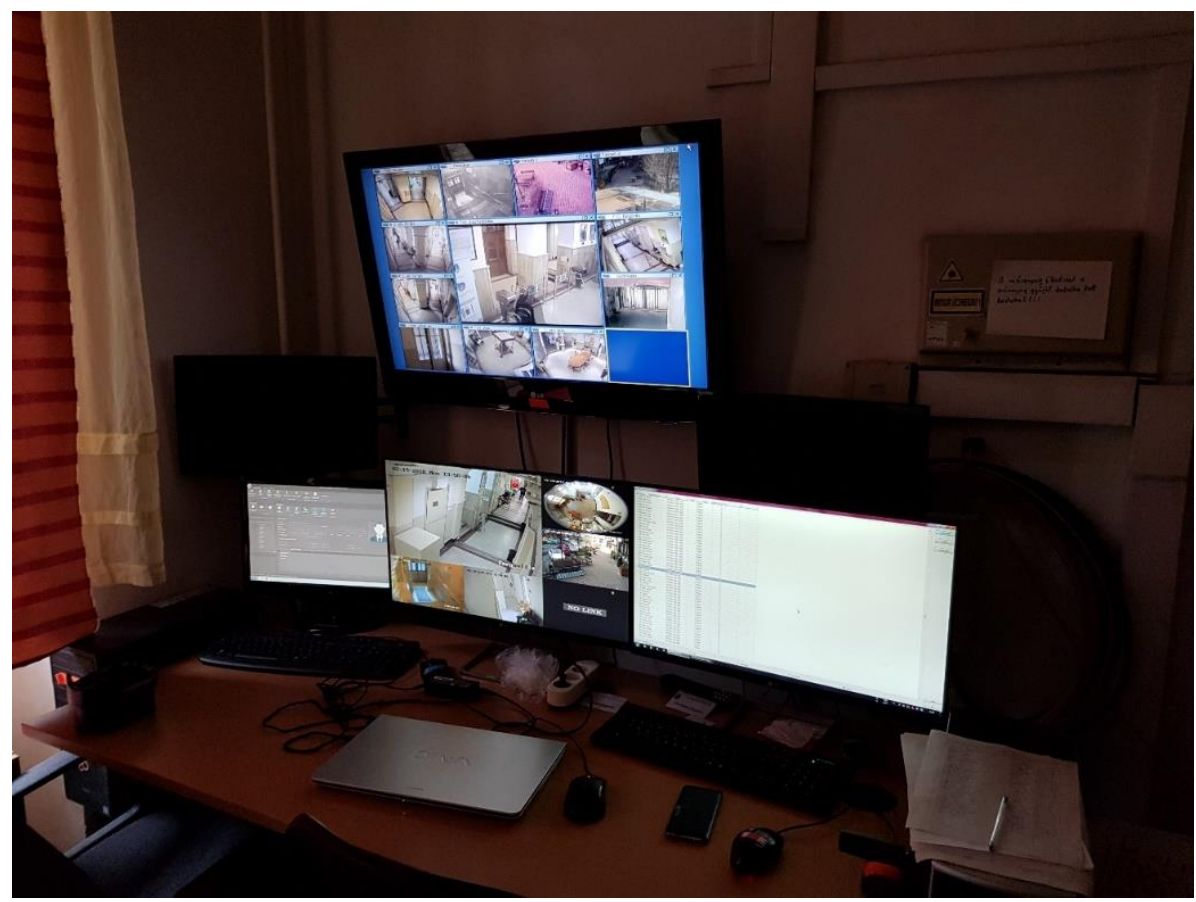

6. ábra Az Óbudai Egyetem megfigyelő helysége (Forrás: Saját készítésű ábra)

A megfigyelő rendszer vagyonvédelmi szolgálatok általi kezelését a személy- és vagyonvédelmi, valamint a magánnyomozói tevékenység szabályairól 2005. évi CXXXIII. törvény: „A személy- és vagyonvédelmi tevékenységet végző személyre vonatkozó szabályok” címü fejezete részletesen tárgyalja. Ezen törvény tartalmazza azon korlátozásokat, amelyek figyelembe vételével üzemeltethet a vagyonőr megfigyelő rendszereket. Fontos az is, hogy a vonatkozó, az információs önrendelkezési jogról és az információszabadságról szóló törvény szerinti adatvédelmi jogok megtartására is egyaránt ügyelni kell. Az elektronikus megfigyelörendszer vagyonör által történő müködtetése csak magánterületen, illetve a magánterületnek a közönség számára nyilvános részén történhet. Az alkalmazás feltétele a megfigyeléshez való hozzájárulás, mely a ráutaló magatartással is megadható. Lényeges az, hogy bizonyos helyeken (pl. öltözö, próbafülke, mosdó, illemhely, kórházi szoba, szociális intézmény lakóhelyisége, stb.) nem lehet elektronikus megfigyelést alkalmazni. A vagyonvédelmi társaságoknak a fenti törvényben foglaltak alapján kell a felvételeket, mint adatokat kezelniük kép-, hang-, vagy kép- és hangrögzítés esetén. Alapesetben, amennyiben a rögzített kép-, hang-, valamint kép- és hangfelvétel nem kerül felhasználásra, a rögzítéstől számított három munkanap elteltével meg kell semmisíteni, illetve törölni kell. [8]

Az egyetemen megfigyelhető, hogy a kritikus behatolási pontokon biztonsági kamerák vannak elhelyezve. Ezt a hetes számú ábrán meg is lehet figyelni: 


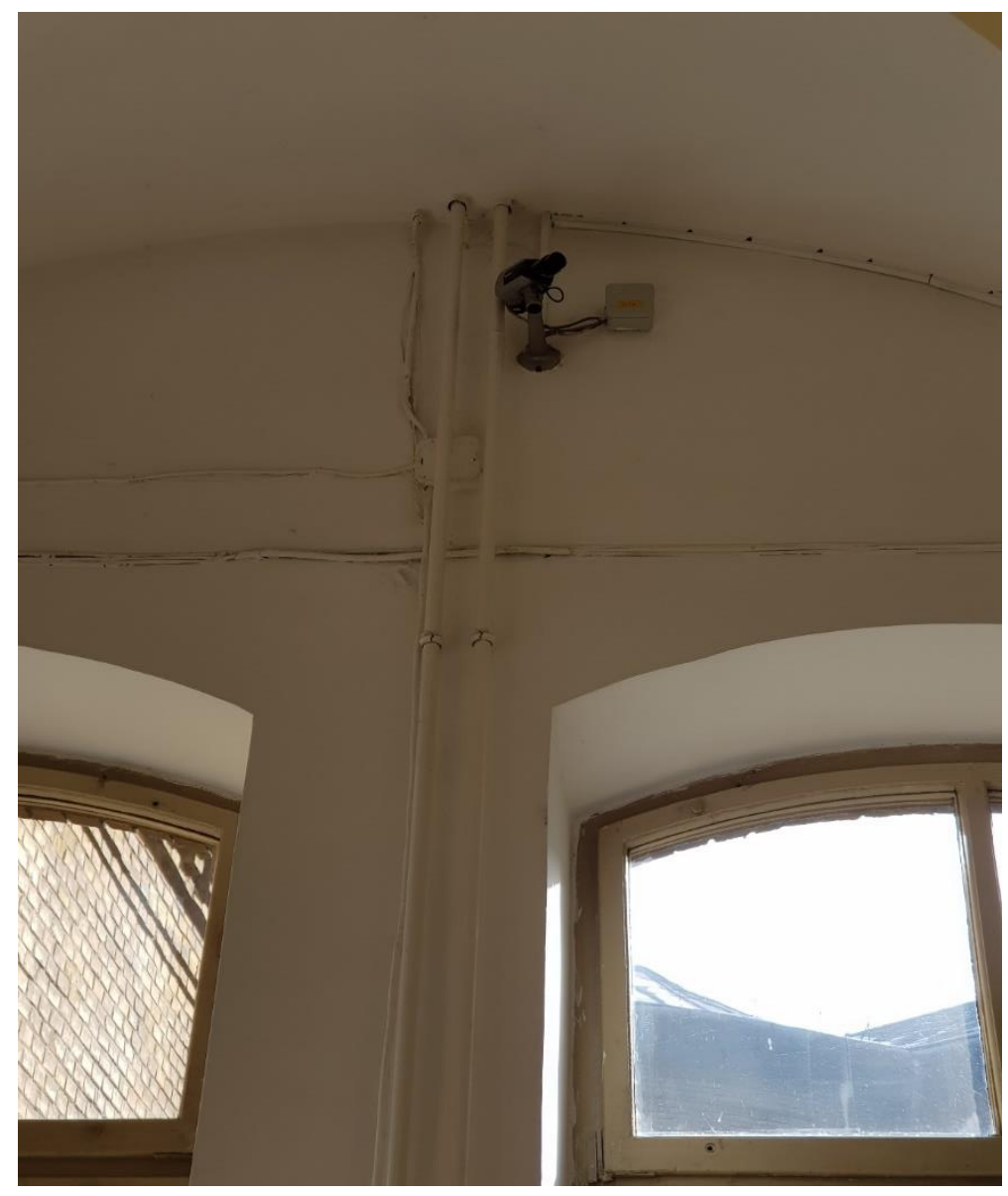

7. ábra Biztonsági kamera az ablakok közelében (Forrás: Saját készítésű ábra)

\section{Tüzvédelmi megoldások az egyetemen}

Az amerikai elöírások szerint a tüzjelzésnek különbözőnek kell lennie más jelzésektől. A magyar szabályozás úgy fogalmaz: „a tüzjelző berendezés tervezése, kivitelezése és üzemeltetése során biztosítani kell, hogy a jelzést egyértelmü figyelemfelhívó tüzriasztás formájában jelenítse meg”. Egy svéd tanulmányból kiderül, hogy az emberek többsége a tűzriadót jelző csengő hangját félreértelmezik. Az adott vizsgálatban csupán $19 \%$-uk ismerte fel, hogy tüzjelzésről volt szó. [9] Az iskolák esetében törvényi elöírás határozza meg a tüzoltó berendezések meglétét. [10]

A porral oltó készülékek a legelterjedtebbek az oktatási intézményekben. Ezeket több féle méretben, súlyban lehet beszerezni. A hat és kilenc kg töltettömeggel rendelkezö készülékeket általában a padlón helyezik el, olyan helyen, hogy az jól látható legyen, illetve, hogy ne zavarjon senkit sem. Az ettöl kisebb készülékeket leggyakrabban a falra szokták rögzíteni, mint ahogyan a nyolcadik számú ábrán is jól látszódik: 


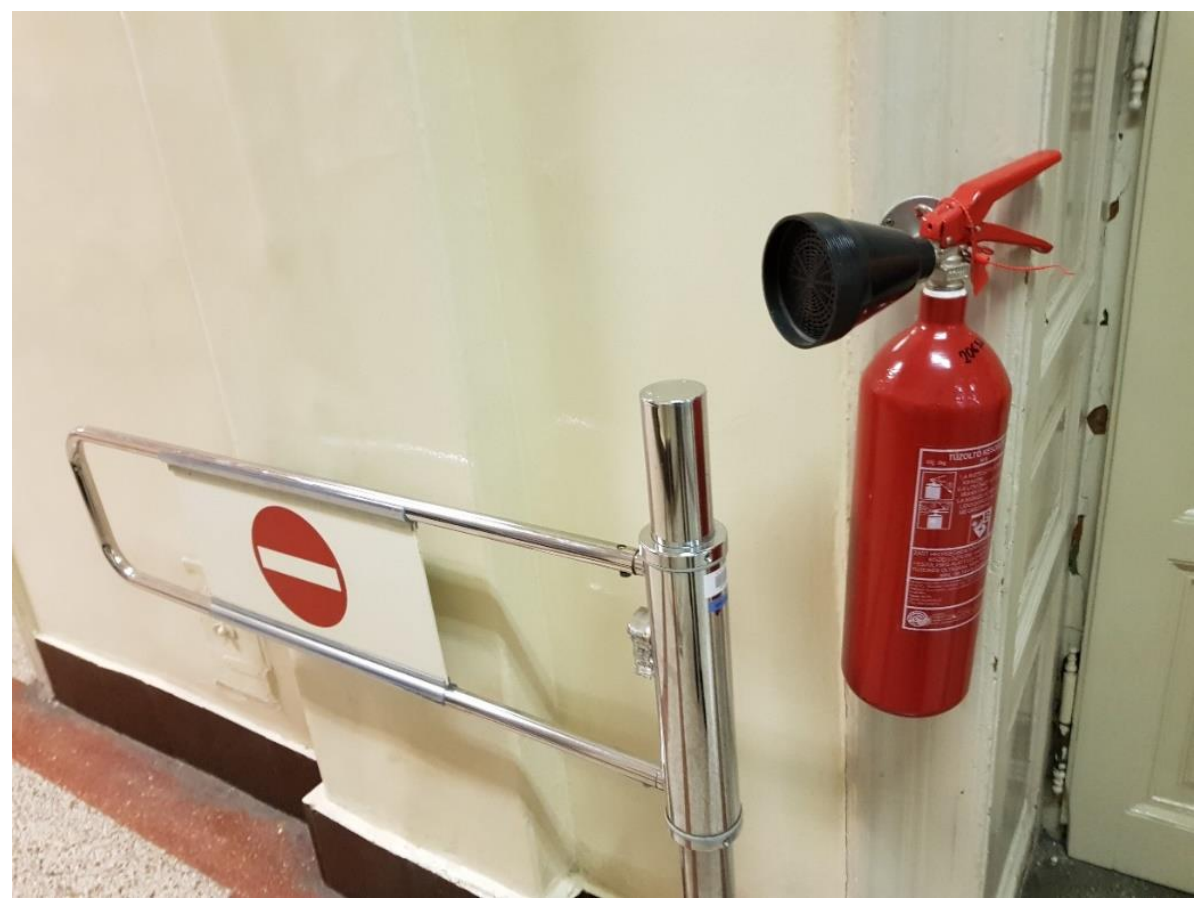

8. ábra Porral oltó készülék az Óbudai Egyetemen (Forrás: Saját készítésű ábra)

A tủzvédelmi megoldások mellett, további nem elhanyagolható tényezőként szolgál egy alapvető szintü jártasság a tüzoltás területén. Ebből kifolyólag az egyetemi dolgozók meghatározott időközönként részt szoktak venni ilyen típusú képzéseken. A porral oltó készülékek igen hatékonynak bizonyulnak kezdődő tüz esetén, azt azonban nem szabad elfelejteni, hogy az alkalmazásuk során rövid idő alatt kiürülnek. Ebből kifolyólag szükséges a fentiekben említett alapvető szintű jártasság és továbbá az a gyakorlati tudás, amely szükséges ahhoz, hogy a lehető legrövidebb időn belül eloltsunk egy nem várt tüzet, hiszen még laikusok számára is az átlagos 15 másodperces müködési idő is nagyon kevésnek tünhet. Bizonytalanságnak, tanácstalanságnak nincs helye ilyen esetekben. A porral oltó készüléknek az útmutató olvasása tüz esetén több, mint kiábrándító tud lenni, valamint magas szintü tüzbiztonsági kockázatot rejt magában. Az Óbudai Egyetem udvarán ebből kifolyólag meghatározott időközönként tüzvédelmi gyakorlati oktatásra is sor szokott kerülni.

\section{Újraélesztő készülék: Defibrillátor}

Az emberi élet megmentéséhez számos eszközre van szükség. Az egyik ilyen a defibrillátor. Sajnos ezek az eszközök igen drágák, illetve a karbantartásuk sem olcsó az akkumulátorukból kifolyólag, amelyet pár évente cserélni kell (általában két évente).

Kijelenthető, hogy a sikeres újraélesztés egyik eszköze a defibrillátor, amely az egyetemen is megtalálható. Nagyon hasznos és átgondolt, hogy a készülék fölött az útmutató is megtalálható. Ezt a kilencedik ábra szemlélteti: 


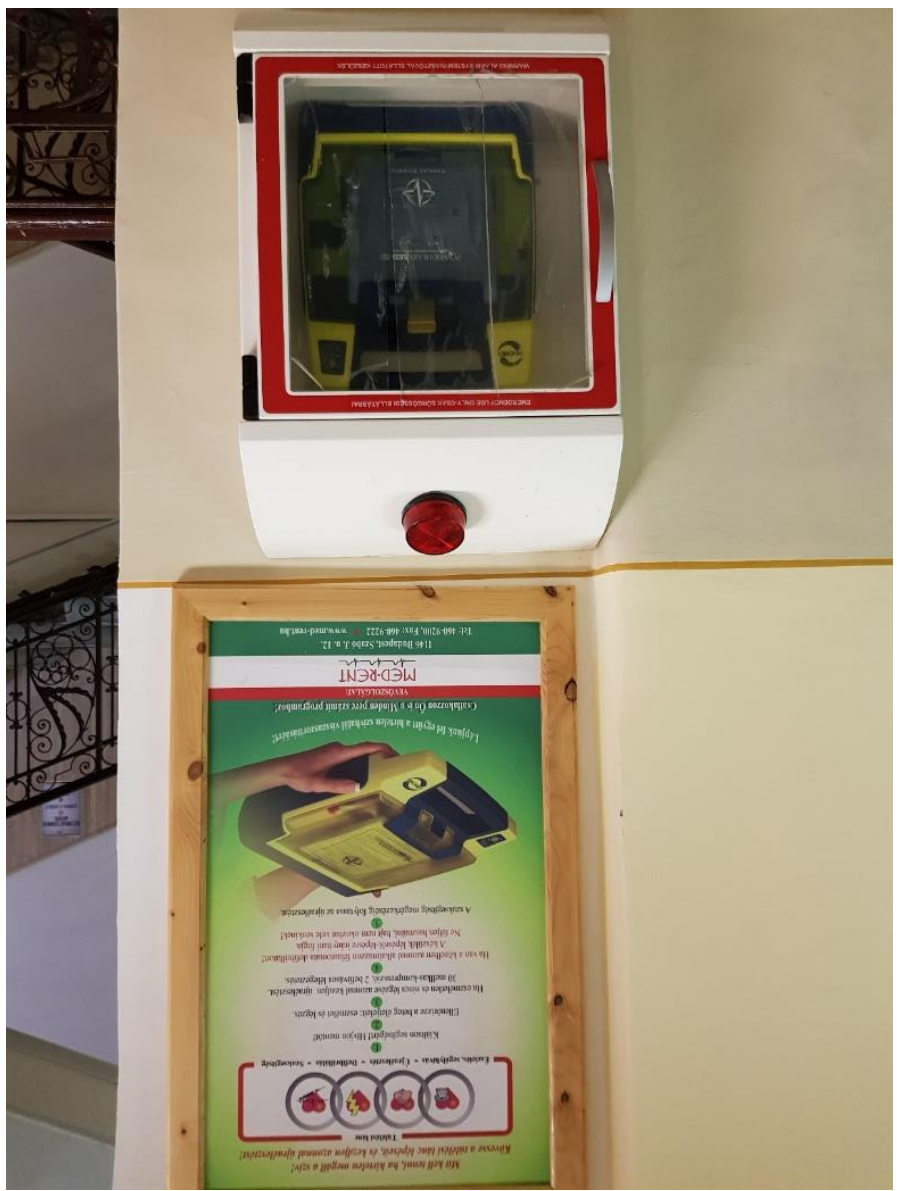

9. ábra Újraélesztő készülék az Óbudai Egyetemen (Forrás: Saját készítésű ábra)

Az időben elkezdett defibrillálásnak köszönhetően a túlélés aránya $65 \%$, amely az első öt percben meg kell, hogy történjen. [11] Ez a mondat kell, hogy lebegjen mindannyiunk szeme előtt, mert sosem tudni, hogy mikor kerül sor ennek az eszköznek a hirtelen és megfelelő használatára, mely segítségével akár nagy eséllyel életeket is menthetünk.

\section{KÖVETKEZTETÉSEK}

Kijelenthető, hogy az Óbudai Egyetem Népszínház utcai kampuszán számos olyan biztonságtechnikai megoldás áll a rendelkezésre, amely a hallgatók és az ott dolgozók biztonságát növeli. Továbbá megállapítható az is, hogy az egyetem mindent megtesz a tanulók biztonsága érdekében, úgy mechanikai, mint elektronikai védelem területén. A biztonsági kamerarendszer, portai szolgálata mind-mind a hallgatók biztonságát növeli, ebböl kifolyólag feltételezhető, hogy illetéktelen személy az egyetem területére nem tud bejutni.

Pozitív törekvések számít, hogy a tủzvédelmi megoldásoknak is eleget tesz az oktatási intézmény. Az egyetem elkötelezett hozzáállását bizonyítja a defibrillátor megléte is, amely nagyban hozzájárulhat akár egy sikeres újraélesztéshez.

Összességében bátran következtetésként levonható, hogy az egyetem naprakész biztonságtechnikai megoldásokat alkalmaz, mely megnyugvásként szolgálhat, mint a diákoknak, mint az oktatóknak, csak úgy, mint a többi ott dolgozó embernek. 


\section{FELHASZNÁLT IRODALOM}

[1] KISS, S.: A biztonságtechnika kialakulásának történetéröl. Hadmérnök X. kiadás 4, December 2015.

[2] LUKÁCS Gy., GÁBOR L.: Új vagyonvédelmi nagykönyv, CEDIT Kft., Budapest, 2002

[3] BEREK, T., HORVÁTH T.: Fizikai védelmi rendszerek dinamikusan változó környezetben. Hadmérnök 9.2 (2014): 16-24.

[4] BUNYITAI Á.: A ma és a holnap beléptető rendszereinek automatikus személyazonositó eljárásai biztonságtechnikai szempontból. Hadmérnök VI. évfolyam 12011.

[5] BUNYITAI Á.: A beléptetö rendszerek helye és szerepe a vagyonvédelemben." Hadmérnök 1 2011: 1 7-25.

[6] BEREK, L., BEREK, T., BEREK, L.: Személy-és vagyonbiztonság, ÓE-BGK 3071. Budapest: Óbudai Egyetem, 2016.

[7] BÁLINT, K.: A vajdasági, szabadkai középiskolában dolgozó tanárok meglátásai az elektronikai és mechanikai iskolai védelem területén. XXIII. Fiatal Müszakiak Tudományos Ülésszaka, Kolozsvár, 2018.

[8] HORVÁTH J.: A zártláncú videó megfigyelö rendszerek jövője. Hadmérnök 8.1, 2013.

[9] SCHÜLLER A.: Az emberi tényező és a technikai megvalósitások vizsgálata tüzriadók során. Hadmérnök 2012. 2. szám p. 37-46. 2012.

[10] BÁLINT, K.: Vajdasági, szabadkai általános iskolában dolgozó tanárok elearning alapú tüzvédelmi képzés iránti igényeinek feltérképezése. III. Kárpát-medencei Oktatási Konferencia, Nagyvárad, 2018.

[11] ,DIÓSZEGHY G.: Az újraélesztés időszerü gyakorlata és kérdései, Központi Aneszteziológiai Intenzív és Betegellátó Sürgősségi Osztály, ResearchGate 2005. 